\title{
The Islamic Financial Services Act 2013: An Overview and Appraisal
}

\author{
Hakimah Yaacob*
}

More than two decades after the enactment of the Islamic Banking Act 1983 and Takaful Act 1984, a new legal framework has been drawn up. The Islamic Financial Services Act 2013 (IFSA 2013) seeks to provide for the regulation and supervision of Islamic financial institutions, payment systems and other relevant entities. The Act came into force on 30 June 2013 and consolidated all laws related to Islamic banking and takaful into one Act. The Act contains 291 sections and is divided into 18 parts with 16 schedules. It covers inter alia the oversight of the Islamic money market and Islamic foreign exchange market to promote financial stability and compliance with Shariah.

The new legal framework will not only streamline the legal requirements across sectors, but will also ensure that the law is reflective of the nature and features of Shariah contracts and that the degree of regulation will commensurate with the level of risks that Islamic financial institutions, markets and products pose to the overall financial system. The Act lays the foundation for a comprehensive regulatory regime to promote a robust and resilient Islamic financial system in Malaysia. It repeals the Islamic Banking Act 1983 [Act 276] and the Takaful Act 1984 [Act 312]. IFSA 2013 also imposes more stringent obligations on financial holding companies and helps strengthen regulation, supervision and governance of financial services groups. In line with the current challenges in the global banking landscape, IFSA gives the central bank stronger supervisory and regulatory oversight of financial services groups. The Act enhances the level of governance and disclosure between financial holding companies and their subsidiaries.

In sum, the new law has changed the whole spectrum of the Islamic banking and takaful operations. The industry believes there are drastic changes in the game. However, positive attitude is believed to be key in accepting the changes. Below are some of the main features of the new Act;

i. IFSA 2013 has articulated the Shariah governance concept into the law for the first time in history with regard to the Islamic finance industry. Shariah non compliance will amount to a violation of law. Strict penalties of up to RM25 million are imposed on those who are in breach of Shariah and failed to comply with Shariah in their business, operation, aim and objectives.

ii. IFSA 2013 also regulates the roles and responsibilities of actuaries, auditors and Shariah committees and it places greater emphasis on consumer 
protection. The implication of IFSA 2013 would be felt more deeply in the takaful industry due to the higher number of composite licenses issued to them compared to their conventional insurance counterparts. It will intensify the recruitment of talent, hence mergers, cost implications and acquisitions between companies is expected.

iii. IFSA 2013 distinguishes investment account from Islamic deposit. An investment account is defined by the application of Shariah contracts with non-principal guarantee feature for the purpose of investment. Notwithstanding this, IFSA 2013 provides adequate legal basis to support the further strengthening of investment account operations that provides appropriate protection to investment account holders (IAH) whilst ensuring stability of the Islamic financial system. Mudarabah accounts, which are based on the concept of profit sharing, should not be deemed to be deposit accounts, as in the current practice, because under this principle, there can be no guarantee that the principal amount will be protected.

iv. Deposits under the investment account like musharakah and mudarabah are no longer guaranteed by Perbadanan Insurans Deposit Malaysia (PIDM). Currently, all depositors (whether business or individuals) are insured by Perbadanan Insurans Deposit Malaysia (PIDM) up to RM250,000 per depositor per member financial institution. Mudarabah deposits, once classified as investment accounts, may no longer be guaranteed by PIDM.

v. Additional cost is associated with the changes in the operational systems, which may affect the end user. This may involve miscellaneous charges imposed on the customer.

vi. The IFSA 2013 increases the general and specific duties of directors. The general duties of directors include the duty to act in good faith in the best interests of the institution; to exercise reasonable care, skill and diligence; and to exercise sound and independent judgment. As for the specific duties under the IFSA 2013, directors are required to ensure and oversee the effective design and implementation of sound internal controls, compliance and risk management systems as well as to set and oversee the implementation of business and risk strategies. These duties complement and do not derogate from the duties of directors under the Companies Act 1965. It should also be noted that in discharging their duties, directors need to have regard to the interest of depositors or policy owners, which may present a potential conflict with the duty to act in the interests of the company and its shareholders.

vii. A number of these requirements, such as the material disclosure provision, are not new. They previously existed under the Bank Negara (Central Bank of Malaysia) Guidelines but have now been codified by the IFSA 2013. This means that breaches will attract statutory penalties, such as the removal of 
the directors, imprisonment for a term of up to eight years and/or a fine of up to RM25 million.

viii. A major change brought by IFSA 2013 is the separation of family and general licenses into independent entities by 2018. It is clearly stated in Section 16 (1) that a licensed takaful operator, other than a licensed professional takaful operator, shall not carry on both family takaful business and general takaful business.

ix. IFSA 2013 has redefined takaful as "an arrangement based on mutual assistance under which the takaful participants agree to contribute to a common fund providing for mutual financial benefits payable to the takaful participants or their beneficiaries on the occurrence of pre-agreed events". The prior definition of takaful in Takaful Act 1984 was "a scheme based on brotherhood, solidarity and mutual assistance which provides for mutual financial aid and assistance to the participants in case of need whereby the participants mutually agree to contribute based on that purpose". The new definition of takaful has been enhanced, more accurate and definitely important.

x. It should be noted that the minimum capital requirement for takaful operators is no longer explicitly defined in the governing Act. Instead, IFSA 2013 states that the regulator will specify the minimum capital requirement. Previously, a minimum capital requirement of RM100 million was explicitly stated in the Takaful Act 1984.

xi. IFSA 2013 has introduced section 133 known as the "financial ombudsman scheme" which means "a scheme for the resolution of disputes between an eligible complainant and a financial service provider in respect of financial services or products". It further explains that "eligible complainant" means any person who is eligible to refer a dispute to a financial ombudsman scheme in accordance with the terms of reference of the scheme". Terms of the scheme set out the followings as required under IFSA 2013 are:

1. Types of disputes

2. Eligible complainants

3. Membership requirements

4. Application, operations and procedures

5. Fees to be charged

6. Types of award to be granted

In a concept paper issued on 29 August 2014, Bank Negara Malaysia explained the approach and dispute resolution mechanism involved. However, settlement of disputes via mediation and adjudication without looking into other aspects or other methodologies has been scaled down. To date, no terms 
of reference has been spelt out by Bank Negara pertaining to this scheme. The industry is definitely keen to know more about the alternative to the court system by having this scheme. The establishment of the scheme is for the purposes of ensuring effective and fair handling of complaints and for the resolution of disputes in connection with financial services or products.

In conclusion, IFSA 2013 provides greater clarity and transparency in the implementation of the law. This includes clearly defined regulatory objectives and accountability of Bank Negara Malaysia in pursuing its principal object to safeguard financial stability. The Act provides transparent triggers for the exercise of Bank Negara Malaysia's powers and functions, and transparent assessment criteria also for authorising institutions to carry on regulated financial business, and for shareholder suitability. There is a clear focus on Shariah compliance and governance in the Islamic financial sector.

\section{Notes}

* Hakimah Yaacob is Associate Fellow at IAIS Malaysia. She can be contacted at hakimah@iais.org.my. 